$\begin{array}{ll}\text { Research Square } & \begin{array}{l}\text { Preprints are preliminary reports that have not undergone peer review. } \\ \text { They should not be considered conclusive, used to inform clinical practice, } \\ \text { or referenced by the media as validated information. }\end{array}\end{array}$

\title{
Quality of Life among Infertile Couples in Gaza City, Palestine
}

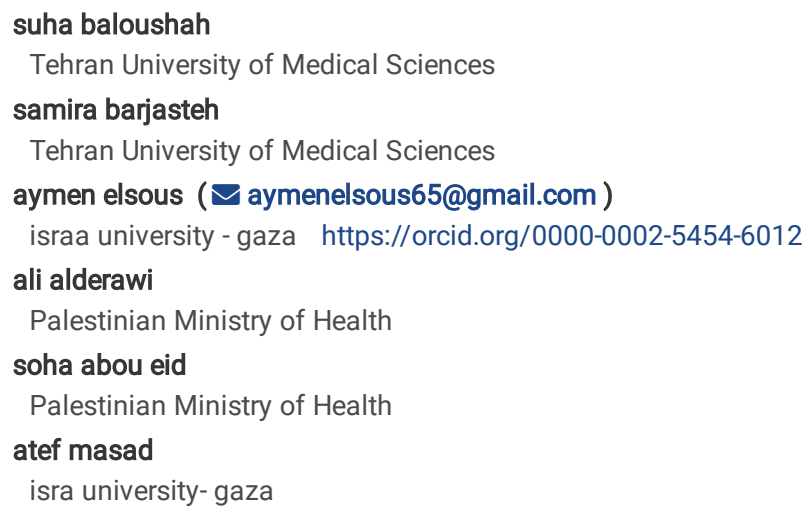

\section{Research}

Keywords: Quality of Life, Infertile couples, Gender, Palestine

Posted Date: March 2nd, 2020

DOI: https://doi.org/10.21203/rs.3.rs-15541/v1

License: (c) (1) This work is licensed under a Creative Commons Attribution 4.0 International License. Read Full License 


\section{Abstract}

Background: Infertility is an important health problem affecting the quality of life accompanied by significant emotional and psychological consequences. Infertile couples living with emotional disturbances face challenges with less success of infertility treatment.

Purposes: This study aimed to investigate the quality of life of infertile couples who seek In-Vitro Fertilizations (IVFs) by gender in Gaza city, Palestinian. Methods and materials: A cross sectional study was conducted, from Feb 2018 to Nov 2018, among 383 infertile couples selected through convenient sampling. A valid and reliable Arabic version of the fertility quality of life questionnaire (FertiQoL) was used in data collection. One way ANOVA and independent t-test was applied to compare between males and females. P value less than $0.05 \%$ was considered statistical significance.

Results: The mean age of males and females was $34.54 \pm 8.54$ and $29.28 \pm 6.71$ years respectively. More than half of them had university degree ( $64 \%$ and $60 \%$ respectively). The mean duration of infertility of couples was $5.66 \pm 3.54$ years. The mean males' scores of FertiQoL and its subscales (emotion, mind/body, social, core, tolerability and treatment) were significantly higher than females' scores $(p<0.05)$.

Conclusion: The males' total scores of FertiQoL and its subscales were higher than females' scores. The mean total of FertiQoL increased with better education, however, decreased with increase of age, duration of marriage, duration of infertility and number of IVF attempts. Psychological assessment and Counseling are necessary for infertile women taking into considerations factors affecting their QoL.

\section{Introduction}

Quality of life is one of the most important components of health. The concept of quality of life is defined in different ways and can be interpreted in three ways. The first definition of the welfare aspects of a person's life; the second definition is related to the economic, social and physical abilities and the third definition is dealing with symptoms or specific disease. Measurement of quality of life makes it possible to understand the needs of the clients and thus improve the quality of the services $(1,2)$. Different factors affect the quality of life of individuals. Infertility is one of the most difficult and effective conditions for quality of life and one of the most common problems in today's world (3).

According to the World health Organization (WHO), infertility is as an important problem in reproductive health, which is not a disease but it can cause significant emotional disturbances and cause social and psychological consequences (4). In a study $12 \%$ of infertile women had low quality of life, while more than half of them had a decent quality of life. Family and community pressure on the quality of life of infertile women had a significant negative impact (5). Infertile women are more vulnerable to undesirable quality of life than men, and support measures for both sexes, especially women, are essential (6). The prevalence of infertility varies among ethnic groups and races, and is about $10-15 \%$, and its incidence has increased by about $50 \%$ over the past decade (79).

In dealing with spiritual issues, couples' participation can be a good solution because there is a positive result in each issue of common life between couples (10). According to the results of the research conducted in comparison with the stressful events of life, infertility after the death of the mother, the death of the father and betrayal of the spouse is in the fourth place (11). One cause of infertility can be physical disease such as the Polycystic Ovary Syndrome, which accounts for $5-10 \%(12)$.

Infertility predisposes individuals to depression and anxiety. The emotional disturbances of infertile couples and secondary symptoms of infertility create a defective cycle that reduces the likelihood of treatment of infertility (13). On the other hand, infertility treatments cause harmful effects on the physical, economic, and psychosocial aspects reducing self-confidence and disrupting masculinity in men and femininity in women (14). That is why, infertility is considered as defeat in the view point of couples and having a baby is one of the best events that happen for a couple. Also, in the reverse condition, infertility affects the same amount of a couple lives (15). Infertility can be one of the reasons for divorce (16). Also, nearly half of infertile women do not have marital adjustment and experienced problems in their relationship with their spouses. Lower sexual satisfaction in infertile couples than fertile couples was reported. As the treatment progresses, the stress level increases significantly and marital satisfaction decreases (17).

In general, different researchers have different opinions about the effect of infertility on couples' relationships. Some researchers believe that tolerating diagnosis and treatment of infertility causes couples to be more intimate, and they will feel closer to each other (18). While many researchers reported declining marital couples' performance as a result of infertility. They have emphasized the increase in marital conflicts among infertile couples (19). As mentioned, quality of life of infertile couples can be varied by ethic, culture and geographical aspects. In this regard, this study aimed to investigate the quality of life (QoL) of infertile couples who seek IVF in Gaza city, Palestinian.

\section{Methods And Materials Study design and setting}

This study is a cross sectional survey, was conducted on 383 infertile couples who seek IVFs services in Alhello, Al Bassma and Al-Hindawy infertility clinics in Gaza city.

\section{Data collection and measurement}

Data were collected for nine months from February 19th, 2019 to November 2019 by three trained midwifes worked in the selected infertility clinics. Eligible couples met the inclusion criteria: primary or secondary infertility, over 18 years of age and willingness for participation in the study. The couples were asked to fill the fertility quality of life questionnaire (FertiQoL) while waiting for medical appointment following face to face interviewing. FertiQoL questionnaire 
consists of 34 questions and measured QoL on two sections, core (24 questions) and treatment (10 questions) (20). In addition to two questions asked about personal health and satisfaction with QoL in general. Average time to fill the questionnaire was 25 minutes.

\section{Sample and sampling}

A convenience sample of 390 couples were approached however three women and two males refused to participate and two women provided incomplete questionnaire and the missing value was more than $5 \%$. Thus, 383 couples involved and participated. Sample size was calculated according to traditional formula of cross-sectional design (21).

\section{Ethical issues}

The couples were provided with explanation about the purpose of the study and confidentiality of information was assured. Participation was voluntary-based and women were asked to give consent prior starting the study. Permission was obtained from administration of the involved infertility clinics in Gaza city and from Ministry of health, department of research. Data are kept in the first author closet and will be discarded once publication is made.

\section{Statistical analysis}

Prior analysis, data were checked for completeness, outliers and errors. Data were analyzed using the IBM SPSS 22 (SPSS Inc., Chicago, III). Continuous variables (age, marital years, no of deliveries,..) were presented as mean and standard deviation. Categorical variables (gender, level of education, menstruation pattern, ..) were presented as frequency and percentage. Mean score of FertiQoL and its subscales, with regard to independent variables, were compared between males and females using one way ANOVA and independent t-test. Analysis used p value less than $0.05 \%$ as statistical significance.

\section{Results}

\section{Characteristics of respondent couples}

The mean age (SD) of females and males was 29.28 (6.71) and 34.54 (8.54) years old respectively. More than half of them had university degree and more ( $60 \%$ and $64 \%$ respectively. Majority of females were housewives (77.2\%), whereas, $75.7 \%$ of males had job. The mean duration of marriage was 7.94 (2.32) years. More than one third of women had been previously delivered a baby and $40 \%$ of them had at least delivered one child. The mean duration of fertility of couples was 5.66 (3.54) years and $71.1 \%$ had experiences IVF at most twice (Table 1). 
Table 1

characteristics of participated women and men

\begin{tabular}{|c|c|c|}
\hline Characteristics & $\begin{array}{l}\text { Female } \\
\mathrm{n}(\%)\end{array}$ & $\begin{array}{l}\text { Male } \\
\text { n (\%) }\end{array}$ \\
\hline $\begin{array}{l}\text { Age }(\mathrm{M} \pm \mathrm{SD}) \\
\leq 30 \text { years } \\
>30 \text { year }\end{array}$ & $\begin{array}{l}29.28 \pm 6.71 \\
254(64.3) \\
140(35.4)\end{array}$ & $\begin{array}{l}34.54 \pm 8.54 \\
156(39.5) \\
239(60.5)\end{array}$ \\
\hline $\begin{array}{l}\text { Living place } \\
\text { North of Gaza } \\
\text { Gaza city } \\
\text { Middle area } \\
\text { South of Gaza }\end{array}$ & $\begin{array}{l}72(18.2) \\
184(46.6) \\
68(17.2) \\
71(18.0)\end{array}$ & \\
\hline $\begin{array}{l}\text { Education } \\
\text { Illiterate } \\
\text { Up to sec. school } \\
\geq \text { University }\end{array}$ & $\begin{array}{l}25(6.3) \\
133(33.7) \\
237(60.0)\end{array}$ & $\begin{array}{l}41(10.4) \\
101(25.6) \\
253(64.0)\end{array}$ \\
\hline $\begin{array}{l}\text { Job } \\
\text { Have a job } \\
\text { Jobless }\end{array}$ & $\begin{array}{l}90(22.8) \\
305(77.2)\end{array}$ & $\begin{array}{l}299(75.7) \\
96(24.3)\end{array}$ \\
\hline $\begin{array}{l}\text { Duration of marriage } \\
\leq 10 \text { years } \\
>10 \text { years }\end{array}$ & $\begin{array}{l}7.94 \pm 2.32 \\
293(74.2) \\
102(25.8)\end{array}$ & \\
\hline $\begin{array}{l}\text { Classification of infertility } \\
\text { Primary } \\
\text { Secondary }\end{array}$ & $\begin{array}{l}240(60.8) \\
155(39.2)\end{array}$ & \\
\hline $\begin{array}{l}\text { Duration of infertility } \\
\leq 3 \\
4-6 \\
>6\end{array}$ & $\begin{array}{l}5.66 \pm 3.54 \\
122(30.9) \\
134(33.9) \\
138(34.9)\end{array}$ & \\
\hline $\begin{array}{l}\text { Previous IVF } \\
\text { Yes } \\
\text { No }\end{array}$ & $\begin{array}{l}278(70.4) \\
117(29.6)\end{array}$ & \\
\hline $\begin{array}{l}\text { Previous no. of IVFs } \\
\leq 2 \\
>2\end{array}$ & $\begin{array}{l}1.86 \pm 1.86 \\
281(71.1) \\
112(28.4)\end{array}$ & \\
\hline $\begin{array}{l}\text { Infertility cause } \\
\text { Wife related cause } \\
\text { Husband related cause } \\
\text { Both } \\
\text { Unknown }\end{array}$ & $\begin{array}{l}56(14.2) \\
138(34.9) \\
80(20.3) \\
121(30.6)\end{array}$ & \\
\hline
\end{tabular}

\section{Perception about health and quality of life}

Males' responses to question about health revealed that one fifth (19.7\%) rated their health as poor or very poor and $71.1 \%$ perceived their health as good or very good. In turn, $23 \%$ of females rated their health as poor and very poor, while $67.3 \%$ rated their health good and very good. With regard to satisfaction about quality of life, one fifth of males (20.3\%) and $67.3 \%$ were dissatisfied (dissatisfied, very dissatisfied) and satisfied (satisfied, very satisfied) respectively. For females, $20 \%$ and $65.4 \%$ were dissatisfied and satisfied with quality of their life respectively.

\section{Comparison of mean scales of FertiQoL subscales between males and females}

The mean males' scores of FertiQoL and its subscales (emotion, mind/body, social, core, tolerability and treatment) were significantly higher than females' scores $(p<05)$. The quality of infertile men is better than in women (Table 2$)$. 
Table 2

Differences of women and men scores of the subscale of FertiQoL

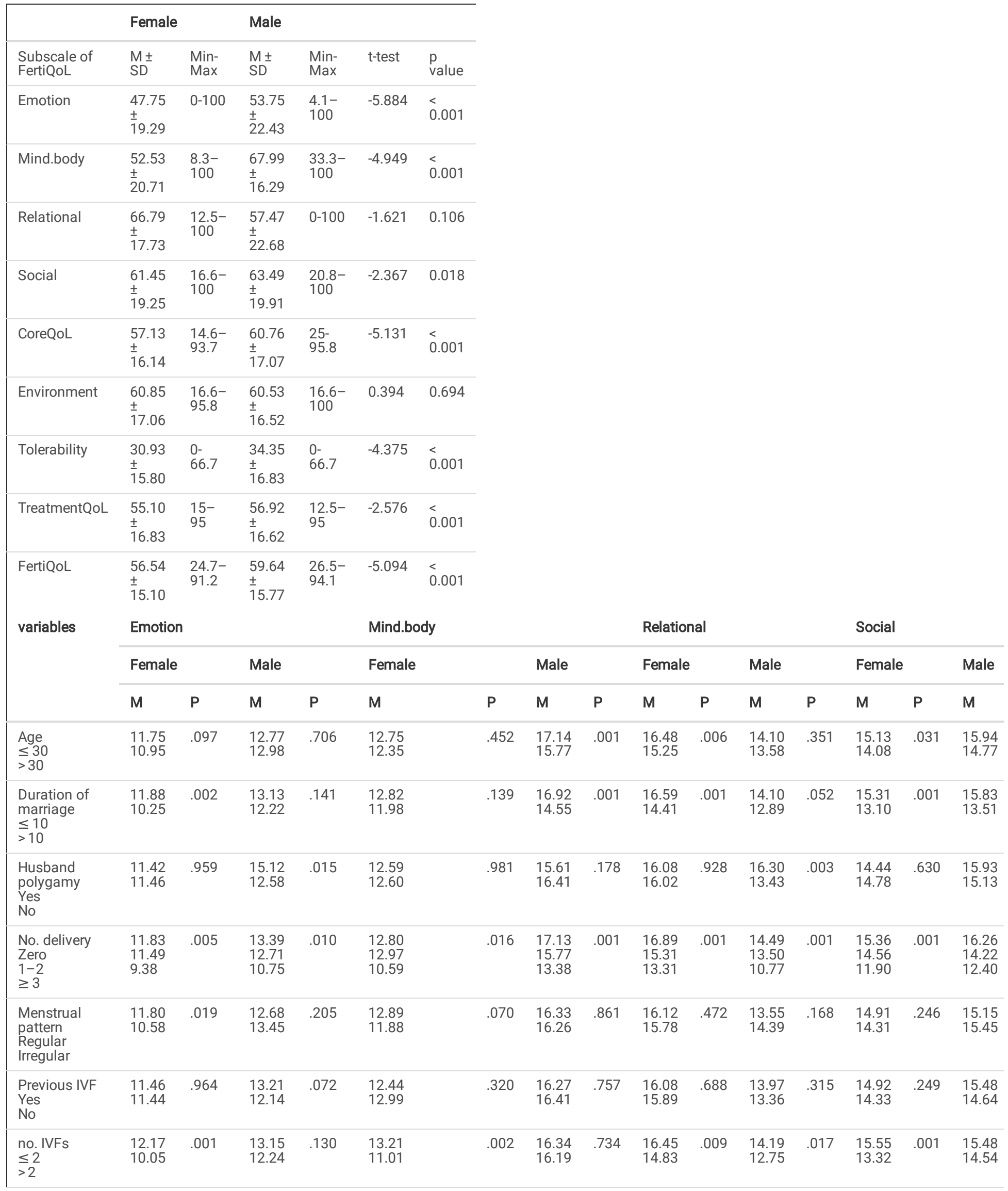




\begin{tabular}{|c|c|c|c|c|c|c|c|c|c|c|c|c|c|c|c|}
\hline & Femal & & Male & & & & & & & & & & & & \\
\hline $\begin{array}{l}\text { Duration of } \\
\text { infertility } \\
\leq 3 \\
4-6 \\
>6\end{array}$ & $\begin{array}{l}11.97 \\
11.33 \\
11.05\end{array}$ & .265 & $\begin{array}{l}13.59 \\
12.44 \\
12.67\end{array}$ & .201 & $\begin{array}{l}13.57 \\
11.88 \\
12.38\end{array}$ & .020 & $\begin{array}{l}16.51 \\
16.50 \\
15.91\end{array}$ & .353 & $\begin{array}{l}16.23 \\
16.08 \\
15.77\end{array}$ & .671 & $\begin{array}{l}14.83 \\
12.92 \\
13.65\end{array}$ & .018 & $\begin{array}{l}15.51 \\
14.43 \\
14.30\end{array}$ & .070 & $\begin{array}{l}16.33 \\
14.83 \\
14.59\end{array}$ \\
\hline $\begin{array}{l}\text { Education } \\
\text { Illiterate } \\
\text { Up to sec. } \\
\text { school } \\
\geq \text { University }\end{array}$ & $\begin{array}{l}10.60 \\
11.31 \\
11.81\end{array}$ & .073 & $\begin{array}{l}13.07 \\
12.89 \\
12.92\end{array}$ & .983 & $\begin{array}{l}11.92 \\
12.60 \\
12.84\end{array}$ & .200 & $\begin{array}{l}15.70 \\
16.34 \\
16.67\end{array}$ & .039 & $\begin{array}{l}16.04 \\
15.90 \\
16.33\end{array}$ & .010 & $\begin{array}{l}13.56 \\
14.26 \\
13.87\end{array}$ & .299 & $\begin{array}{l}13.96 \\
14.72 \\
15.10\end{array}$ & .004 & $\begin{array}{l}14.63 \\
15.67 \\
15.42\end{array}$ \\
\hline \multirow[t]{3}{*}{ variables } & \multicolumn{4}{|c|}{ Tolerability } & Environment & & & & \multicolumn{4}{|c|}{ Treatment } & \multicolumn{3}{|c|}{ Total fertiQoL } \\
\hline & \multicolumn{2}{|c|}{ Female } & \multicolumn{2}{|l|}{ Male } & \multicolumn{2}{|l|}{ Female } & \multicolumn{2}{|l|}{ Male } & \multicolumn{2}{|c|}{ Female } & \multicolumn{2}{|l|}{ Male } & \multicolumn{2}{|l|}{ Female } & Male \\
\hline & $M$ & $P$ & $M$ & $\mathrm{P}$ & $M$ & $\mathrm{P}$ & M & $\mathrm{P}$ & $M$ & $\mathrm{P}$ & $M$ & $\mathrm{P}$ & $M$ & $\mathrm{P}$ & M \\
\hline $\begin{array}{l}\text { Age } \\
\leq 30 \\
>30\end{array}$ & $\begin{array}{l}7.77 \\
6.81\end{array}$ & .015 & $\begin{array}{l}8.75 \\
7.90\end{array}$ & .038 & $\begin{array}{l}15.11 \\
13.75\end{array}$ & .001 & $\begin{array}{l}15.28 \\
14.02\end{array}$ & .002 & $\begin{array}{l}22.91 \\
20.56\end{array}$ & .001 & $\begin{array}{l}24.04 \\
21.93\end{array}$ & .002 & $\begin{array}{l}79.06 \\
73.20\end{array}$ & .006 & $\begin{array}{l}84.24 \\
79.09\end{array}$ \\
\hline $\begin{array}{l}\text { Duration of } \\
\text { marriage } \\
\leq 10 \\
>10\end{array}$ & $\begin{array}{l}7.74 \\
6.49\end{array}$ & .004 & $\begin{array}{l}8.67 \\
7.00\end{array}$ & .001 & $\begin{array}{l}15.13 \\
13.07\end{array}$ & .001 & $\begin{array}{l}15.09 \\
12.89\end{array}$ & .001 & $\begin{array}{l}22.90 \\
19.56\end{array}$ & .001 & $\begin{array}{l}23.77 \\
19.89\end{array}$ & .001 & $\begin{array}{l}79.53 \\
69.32\end{array}$ & .001 & $\begin{array}{l}83.93 \\
73.08\end{array}$ \\
\hline $\begin{array}{l}\text { Husband } \\
\text { polygamy } \\
\text { Yes } \\
\text { No }\end{array}$ & $\begin{array}{l}7.40 \\
7.42\end{array}$ & .977 & $\begin{array}{l}8.40 \\
8.21\end{array}$ & .760 & $\begin{array}{l}14.93 \\
14.55\end{array}$ & 564 & $\begin{array}{l}14.30 \\
14.55\end{array}$ & .678 & $\begin{array}{l}22.34 \\
21.99\end{array}$ & .732 & $\begin{array}{l}22.71 \\
22.77\end{array}$ & .950 & $\begin{array}{l}76.89 \\
76.89\end{array}$ & .999 & $\begin{array}{l}85.69 \\
80.46\end{array}$ \\
\hline $\begin{array}{l}\text { No. delivery } \\
\text { Zero } \\
1-2 \\
\geq 3\end{array}$ & $\begin{array}{l}7.95 \\
7.02 \\
5.61\end{array}$ & .001 & $\begin{array}{l}8.96 \\
7.68 \\
5.86\end{array}$ & .001 & $\begin{array}{l}15.52 \\
13.98 \\
11.36\end{array}$ & .001 & $\begin{array}{l}15.52 \\
13.75 \\
11.22\end{array}$ & .001 & $\begin{array}{l}23.50 \\
21.00 \\
16.97\end{array}$ & .001 & $\begin{array}{l}24.49 \\
21.43 \\
17.09\end{array}$ & .001 & $\begin{array}{l}80.42 \\
75.35 \\
62.18\end{array}$ & .001 & $\begin{array}{l}85.94 \\
77.71 \\
64.40\end{array}$ \\
\hline $\begin{array}{l}\text { Menstrual } \\
\text { pattern } \\
\text { Regular } \\
\text { Irregular }\end{array}$ & $\begin{array}{l}7.58 \\
7.00\end{array}$ & .175 & $\begin{array}{l}8.07 \\
8.66\end{array}$ & .193 & $\begin{array}{l}14.69 \\
14.37\end{array}$ & .494 & $\begin{array}{l}14.51 \\
14.56\end{array}$ & .898 & $\begin{array}{l}22.29 \\
21.38\end{array}$ & .230 & $\begin{array}{l}22.58 \\
23.23\end{array}$ & .386 & $\begin{array}{l}78.04 \\
73.95\end{array}$ & .065 & $\begin{array}{l}80.44 \\
82.80\end{array}$ \\
\hline $\begin{array}{l}\text { Previous IVF } \\
\text { Yes } \\
\text { No }\end{array}$ & $\begin{array}{l}7.18 \\
7.99^{\circ}\end{array}$ & .044 & $\begin{array}{l}8.41 \\
7.84\end{array}$ & .206 & $\begin{array}{l}14.88 \\
13.93\end{array}$ & .050 & $\begin{array}{l}14.93 \\
13.55\end{array}$ & .004 & $\begin{array}{l}22.06 \\
21.96\end{array}$ & .890 & $\begin{array}{l}23.34 \\
21.40\end{array}$ & .016 & $\begin{array}{l}76.98 \\
76.66\end{array}$ & .886 & $\begin{array}{l}82.41 \\
78.02\end{array}$ \\
\hline $\begin{array}{l}\text { Previous no. } \\
\text { of IVFs } \\
\leq 2 \\
>2\end{array}$ & $\begin{array}{l}8.00 \\
5.97\end{array}$ & .001 & $\begin{array}{l}8.63 \\
7.23\end{array}$ & .004 & $\begin{array}{l}14.69 \\
14.33\end{array}$ & .441 & $\begin{array}{l}14.66 \\
14.15\end{array}$ & .251 & $\begin{array}{l}22.71 \\
20.31\end{array}$ & .001 & $\begin{array}{l}23.29 \\
21.38\end{array}$ & .016 & $\begin{array}{l}78.87 \\
71.69\end{array}$ & .001 & $\begin{array}{l}82.58 \\
77.17\end{array}$ \\
\hline $\begin{array}{l}\text { Duration of } \\
\text { infertility } \\
\leq 3 \\
4-6 \\
>6\end{array}$ & $\begin{array}{l}8.39 \\
7.14 \\
6.79\end{array}$ & .002 & $\begin{array}{l}8.96 \\
7.95 \\
7.85\end{array}$ & .053 & $\begin{array}{l}14.51 \\
14.53 \\
14.75\end{array}$ & .867 & $\begin{array}{l}14.75 \\
14.44 \\
14.39\end{array}$ & .743 & $\begin{array}{l}22.90 \\
21.68 \\
21.58\end{array}$ & .220 & $\begin{array}{l}23.72 \\
22.40 \\
22.25\end{array}$ & .155 & $\begin{array}{l}80.21 \\
75.41 \\
75.12\end{array}$ & .085 & $\begin{array}{l}85.09 \\
79.11 \\
79.28\end{array}$ \\
\hline $\begin{array}{l}\text { Education } \\
\text { Illiterate } \\
\text { Up sec. }\end{array}$ & $\begin{array}{l}7.00 \\
7.46 \\
7.56\end{array}$ & .237 & $\begin{array}{l}7.68 \\
9.16 \\
8.14\end{array}$ & .015 & $\begin{array}{l}15.28 \\
14.48 \\
14.91\end{array}$ & .001 & $\begin{array}{l}15.04 \\
14.73 \\
14.77\end{array}$ & .001 & $\begin{array}{l}22.28 \\
21.98 \\
22.47\end{array}$ & .001 & $\begin{array}{l}22.73 \\
23.90 \\
22.92\end{array}$ & .001 & $\begin{array}{l}74.80 \\
76.56 \\
78.56\end{array}$ & .002 & $\begin{array}{l}79.70 \\
83.31 \\
81.90\end{array}$ \\
\hline
\end{tabular}

$\geq$ University

Relationship between women's and men's characteristics and the

subscale of FertQoL

\section{Relationship between couples' characteristics and FertiQoL subscales}

A significant differences was achieved between women' duration of marriage, number of deliveries, menstrual pattern, number of IVFs performed and emotion score. For men, husband polygamy received highest emotion score. Females achieved lower scores (> 50\%) than males for emotion subscale.

Younger males (below 30 years had significant higher mind/boby and social score $(p<0.01)$. Males scored higher than females for mind/body and significant differences is seen with regard to age groups, education level and duration of marriage $(P<0.05)$. Whereas, differences of females' scores were achieved in the duration of fertility, number of previous deliveries and IFVs. There was a significant difference between age and women's relational, social and core scores.

The females who experienced IVF at least three times had lower score for its core dimensions and its subscales. However, differences are significant in core subscale and FertiQoL as a whole. The males and females below 30 years old reported higher scores for the treatment subscales and significance is achieved in treatment, its subscales and FertiQoL domain. Similar findings are reported for duration of marriage and number of previous deliveries $(\mathrm{p}<0.05)($ Table 3$)$.

\section{Discussion}


The current study aimed to explore QoL and associated factors of infertile couples, who seek IVF, from a dyadic or two perspectives. The results of our study showed that husbands' QoL (in terms of emotion, mind/body, social, core, tolerability and treatment) was more positively affected than was their counterparts women, similar to a conclusion drawn by Goker and his colleagues (22). Infertility is a stressful status affects individual's health including emotions especially in women. The traditional social pressure in Palestinian society enhances husbands to have a large number of children especially when infertility is women factor. Infertile Women feel inferior and disappointed $(23,24)$. Infertility could be life-long and interventions including medical treatments are subjected to failure, thus, psychological, social and economic effect is expected. Emotional, support, therapeutic and psychological counseling are vital contributing features for improving quality of life for infertile women (25-27).

Our findings indicated differences in the relation between QoL and age. Youngers have better QoL than infertile individuals above 30 years old similar to Khayata et al. (28). Significant differences were seen in the score between infertile men and women in the Core QoL, treatment QoL and overall FertiQoL. This is against findings of Goker and his colleagues study (22), Karabulut, Ozkan \& Oguz (26) and Bolsoy et al., (29). Social and psychological support including counseling, to elders, are necessary to infertile couples and raise awareness of society toward infertility as a health issue not defect or deficiency.

It is acknowledged that education level has a significant impact on infertile QoL. Infertile individuals of lower education are more prone to social stigma and thus are under much stress (30). In our study, high education level was a positive influencing factor similar to previous study of Karabulut, Ozkan \& Oguz (26). As the education level of infertile individuals' increases, the QoL improves. Better education contributes to coping and adaptation to stressful experiences. In contrast lower education level might increase depression of infertile couples and makes dyadic adjustment and coping to anxious situation inadequate and difficult (30). In this study, men with higher education obtained better scores in the environment and treatment subscales; however, women obtained better scores in the core, social, relational, environment and treatment subscales. Previous studies reported no relationship between the women's educational level and FertiQoL subscale scores (31). Differences of findings could be attributed to using of various instruments and variations in the socio-demographic background of participated subjects.

Significant relationship is noticed between duration of marriage and QoL. Men married for less than 10 years have higher QoL than their counterparts' women (32). However, females QoL were only higher for relational subscale. Similar findings were reported from Chachamovich et al. (33) and Keramat et al. (34). A possible explanation with regard to Arabic context, partners are under family pressure especially from mothers in law to see their grandchildren. In Islamic rules, men have chances to get married to other wives if first married is failed to bring children. In return, women remain anxious and feared as infertility time increases. Fear from their husbands to get a second wife or to reach menopause time with no backbone support or being a mother. Women prefer to have boys because they are the support in front of families and social pressures. One study found no significant effect between QoL and duration of marriage (35).

QoL of infertile women in all FertiQoL subscales decreased with increased number of IVFs attempts, in contrast to their counterparts' men. This is reasonable and acceptable because interventions to treat infertility, including injections, aspiration, intra-cytoplasmic injection, IVFs and medical treatments, are mostly applied to women and women may exposed to physical and psychological complications resulting from interventions. Moreover, increase failures of IVFs attempts could lead to emotional disturbances, frustration and anxiety. Similar finding was reported by Jahromi et al. (2018) and Ragni et al. (2005).

A significant relationship was found between the quality of life and the duration of infertility among men, infertile men for less than 3 years have a significant better QoL (35). Previous studies reported decrease in the QoL as the infertility duration increases $(22,35,37)$. As a source of speculation, infertile men who live in a society, like in the Gaza strip, are in hurry to have children very earlier to satisfy themselves and their families and to overcome social pressure and stigma. However, as the infertility duration increases, men accept and accommodate to situation over time. We found females QoL depends on duration of infertility (38). This is inconsistent with findings of Baghiani Moghadam et al. (39).

\section{Limitations of study}

This study had several limitations; firstly, many independent factors which may affect QoL of infertile couples were not studies. Hereafter, further studies are recommended to exclude potential confounding factors. Secondly, we didn't have control group from fertile couples to compare results. To better understand such effects, doing case control study with large sample size is recommended. Thirdly, the nature of cross-sectional design limits the causal relationship.

\section{Conclusion}

Infertility affects the QoL of infertile Palestinian couples. The males' total scores of FertiQoL and its subscales (emotion, mind/body, social, core, tolerability, and treatment) were higher than females' scores. The mean total fertiQoL increased with better education, however, decreased with increase of age and duration of marriage, duration of infertility and number of IVF attempts.

\section{Abbreviations}

FertiQoL

Fertility quality of life

IVFs

In-vitro fertilizations

QoL

Quality of life

WHO

World health organization 


\section{Declarations}

\section{Consent for publication}

Each couple gave two consents and signatures, for male and female, to participate in this study and publish the findings with all reserved rights. Anonymity was ensured. No pictures were taken or video recorded

\section{Availability of data}

Original data from the study is available with the first author up on request

\section{Funding}

None

\section{Acknowledgement}

The authors are grateful to head of infertility clinics for their permission to act the study. We are also thankful to women who agreed to participate. Many thanks for the midwifes who collected the data

\section{Author's contribution}

SB and AE designed the study. AE, AM and AD wrote the first draft. SB, SB and SE participated in writing the manuscript. AM and SE edited the script before submission, data analyzing was performed by AE. All authors read and approved the final version.

\section{Conflict of interest}

The research has no conflict of interest

\section{References}

1. Schalock RL, Verdugo MA, Gomez LE. Translating the Quality of Life Concept into Practice. InHandbook of Positive Psychology in Intellectual and Developmental Disabilities 2017 (pp. 115-126). Springer, Cham.

2. Karimi M, Brazier J. Health, health-related quality of life, and quality of life: what is the difference?. Pharmacoeconomics, 2016;34(7):645-649.

3. Bayoumi RR, van der Poel SZ, Koert E, Boivin J. Fertility awareness and quality of life: assessment and impact of fertility problems and infertility. Global Reproductive Health, 2018;3(4):e21.

4. Mollaiynezhad M, Jaaferpour M, Jahanfar SH, Jam-shidi R. Infertility related stress and marital life in Iranian infertile women who referred to Isfahan infertility treatment clinic. [Article in Persian]. J Reprod Infertil, 2001;2(1):26-39.

5. Alieh G, Laya F. Quality of life and its correlated among a group of infertile Iranian women. Med Sci Monit, 2007;13(7):CR313-7.

6. Rashidi B, Montazeri A, Abedinia N, Shariat M, Ashrafi M, Ramezanzadeh F. Health-Related Quality of life in Iranian Couples Receiving IVF/ICSI Treatment. Payesh, 2012;11(3):385-389

7. Berek JS, Hillard PJA. Initial assessment and communication. In: Berek JS. Berek \& Novak's gynecology. 14th ed. Philadelphia:Lippincott Williams \& Wilkins;2007:3-25

8. Speroff L, Fritz MA. Clinical gyecologic and endocrinogy and infertility.7th ed. Philadelphia: Lippincott. Williams \& Wilkins; 2005.

9. Ahmadi H. Survey on Relationship between marital satisfaction and irrational communicative belief [Thesis in Persian]. Mashhad: Mashhad University of Medical Sciences; 2003:121.

10. Rabiepoor S, Khodaei A, Valizadeh R. Husbands' participation in prenatal care and breastfeeding self-efficacy in Iranian women: A randomized clinical trial. Medical Journal of the Islamic Republic of Iran, 2019;33(1):353-357.

11. Oddens BJ, den Tonkelaar I, Nieuwenhuyse H. Psychosocial experiences in women facing fertility problems-a comparative survey. Human reproduction (Oxford, England), 1999; 14(1):255-261.

12. Foroozanfard F, Soleimani A, Arbab E, Samimi M, Tamadon MR. Relationship between IL-17 serum level and ambulatory blood pressure in women with polycystic ovary syndrome. Journal of nephropathology, 2017;6(1):15.

13. Amiri M, Chaman R, Sadeghi Z, Khatibi MR, Ranjbar M, Khosravi A. Quality of life among fertile and infertile women. Iranian Journal of Psychiatry and Behavioral Sciences, 2017;11(1): e5641.

14. Vannuccini S, Clifton VL, Fraser IS, Taylor HS, Critchley H, Giudice LC, Petraglia F. Infertility and reproductive disorders: impact of hormonal and inflammatory mechanisms on pregnancy outcome. Human reproduction update, 2015; 22(1):104-115

15. Moura-Ramos M, Gameiro S, Canavarro MC, Soares I, Almeida-Santos T. Does infertility history affect the emotional adjustment of couples undergoing assisted reproduction? The mediating role of the importance of parenthood. British journal of health psychology, 2016;21(2):302-317.

16. Ardekani ZB, Akhondi MM, Kamali K, Khalaf ZF, Eskandari S, Ghorbani B. Mental health status of patients attending avicenna infertility clinic. Journal of Reproduction \& Infertility, 2010; 11(4):319-324. 
17. Donarelli Z, Gullo S, Lo Coco G, Marino A, Scaglione P, Volpes A, Allegra A. Assessing infertility-related stress: the factor structure of the Fertility Problem Inventory in Italian couples undergoing infertility treatment. Journal of Psychosomatic Obstetrics \& Gynecology, 2015;36(2):58-65.

18. Greil AL, Slauson-Blevins K, McQuillan J, Lowry MH, Burch AR, Shreffler KM. Relationship satisfaction among infertile couples: implications of gender and self-identification. Journal of Family Issues, 2018;39(5):1304-1325.

19. Zhuoran W, Wanpeng L, Tao P, Coates R. Qualitative research on infertile Chinese couples' understanding of sexuality. Family practice, 2017;35(1):88-92.

20. Charan J, Biswas T. How to calculate sample size for different study designs in medical research? Indian J Psychol Med, 2013. 35(2): p. 121-6.

21. Boivin J, Takefman J, Braverman A. The fertility quality of life (FertiQoL) tool: development and general psychometric properties. Fertility and Sterility, 2011;96,409-415.e3.

22. Goker A, Yanikkerem E, Birge O, Kuscu NK. Quality of life in Turkish infertile couples and related factors. Human Fertility, 2017;21(3):195-203.

23. Direkvand-Moghadam A, Delpisheh A, Direkvand-Moghadam A. Effect of infertility on the quality of life, a cross- sectional study. J Clin Diagn Res, 2014;8(10): 0C13-

0C15.

24. Huppelschoten AG, van Dongen AJ, Verhaak CM, Smeenk JM, Kremer JA, Nele,

25. Differences in quality of life and emotional status between infertile women and

Their partners. Human Reproduction, 2013;28, 2168-2176.

25. Ried K, Alfred A. Quality of life, coping strategies and support needs of women seeking traditional Chinese medicine for infertility and viable pregnancy in Australia: a mixed methods approach. BMC Womens Health, 2013; 13, 17.

26. Karabulut A, Ozkan S, Oguz N. Predictors of fertility quality of life (FertiQoL) in infertile women: analysis of confounding factors. European Journal of Obstetrics Gynecology and Reproductive Biology, 2013;170, 193-197.

27. Yanikkerem E, Kavlak O, Sevil U. Infertil c, iftlerin yas, adiklari sorunlar ve hems, irelik yaklas, imi [Infertile couple's problems and nursing approach]. Journal of Anatolia Nursing and Health Sciences, 2008; 11, 112-121.

28. Khayata GM, Rizk DE, Hasan MY, Ghazal-Aswad S, Asaad MA. Factors influencing the quality of life of infertile women in United Arab Emirates. International Journal of Gynaecology and Obstetrics,2003; 80, 183-188.

29. Bolsoy N, Taspinar A, Kavlak O, Sirin A. Differences in quality of life between infertile women and men in Turkey. J Obstet Gynecol Neonatal Nurs, 2010;39(2): 191-198.

30. Alibaşoğlu H. Emotional Symptoms in Infertility, Marital Adjustment, and Gender Differences in the context of Sexual Functioning. (A doctoral dissertation). 2010.

31. Kahyaoglu Sut H, Balkanli Kaplan P. Quality of life in women with infertility via the FertiQoL and the Hospital Anxiety and Depression Scales. Nursing and Health Sciences, 2015;17,84-89.

32. Namdar A, Mehdi M, Naghizadeh Zamani M, Yaghmaei F, Sameni M. Quality of life and general health of infertile women. Health and Quality of Life Outcomes, 2017;15, 139.

33. Chachamovich JR, Chachamovich E, Zachia S, Knauth D, Passos EP. What variables predict generic and health-related quality of life in a sample of Brazilian women 
experiencing infertility? Human Reproduction, (2007);22: 1946-1952.

34. Keramat A, Masoomi SZ, Mousavi, SA, Poorolajal J, Shobeiri F, Hazavhei SM.

Quality of life and its related factors in infertile couples. Journal of Research in Health Sciences, 2014;14, 57-63.

35. Marzieh S, Nikvarz F, Zangiabadizadeh M. The quality of life and some effective Factors on infertile couples. Ann Trop Med Public Health, 2017;10:928-238.

36. Çavdar NK, Coşkun AM. The effect of infertility upon quality of life and selfesteem. MOJ Womens Health, 2018;7(3):89-94.

37. Aslzaker M, Pourshahbaz A, Bagheri Lankarani N, Mohammadkhani P, Geranmayepour S. Effects of infertility stress, psychological symptoms, and quality of life on predicting success rate of IVF/ICSI treatment in infertile women. Practice Clin Psychol, 2016;4:275-281.

38. Dillu R, Sheoran P, Sarin J. An Exploratory Study to Assess the Quality of Life of Infertile Couples at Selected Infertility Clinics in Harya. Journal of Nursing and Health Science; (2013); 2(3):45-55.

39. Baghiani Moghadam MH, Aminian AH, Abdoli AM, Seighal N, Falahzadeh H, Ghasemi N. Evaluation of the general health of the infertile couples. Iran J Reprod Med, 2011;9(4):309-314. 